\title{
Eğitim Programı Liderliği Yeterlilikleri Üzerine Bir Araştırma
}

\author{
Oktay AKBAŞ ${ }^{1}$, Serap Nur DUMAN ${ }^{1} \&$ Ahmet KESKIN ${ }^{1}$ \\ ${ }^{1}$ Kırıkkale Üniversitesi, Türkiye
}

Gönderilme Tarihi (Received): $\quad$ 26/10/2021

Düzeltme Tarihi (Revised): $\quad$ 13/12/2021

Kabul Tarihi (Accepted): $\quad$ 14/12/2021

Yayınlanma Tarihi (Published): $\quad 31 / 12 / 2021$

\section{Özet:}

Bu araştırmada öğretmen ve eğitimcilerin bir eğitim programı lideri olarak bilgi, beceri ve yeterliliklerini geliştirmek amaçlanmıştır. Durum öncesi-sonrası araştırma deseninde gerçekleştirilen araştırmanın katılımcıları amaçlı örnekleme modelinden yararlanılarak belirlenmiştir. Farklı üniversitelerde eğitim gören veya çalışan öğretmen, eğitim yöneticisi, ögretim elemanı ve lisansüstü öğrencilerinden seçilen 20 katılımcı araştırmada gönüllü olarak yer almıştır. Araştırmada ilk olarak katılımcıların etkinlik öncesi görüşleri ve değerlendirmeleri alınmıştır. Daha sonra eğitim programı liderliği kapsamında hazırlanan 55 saatlik bilimsel ĕgitim etkinliği ve uygulamalar katılımcılara sunulmuştur. Son olarak katılımcıların ĕgitimler sonrası görüşleri ve değerlendirmeleri alınmıştır. Toplanan veriler betimsel analizden yararlanılarak tema, kategori ve kod olarak sunulmuştur. Elde edilen bulgulara dayalı olarak; eğitim etkinliği öncesinde iki temaya ulaşılmıştır. Bunlar; toplumsal duyarlılık ve sosyal sorumluluk yeterliliği ile çă̆ın sunduğu firsatlara yönelik farkındalık ve yararlanma yeterliliği olarak belirlenmiştir. Eğitim etkinliği sonrasında ise ortaya çıkan temalar currere yöntemi, sosyal sorumluluk, çağın sunduğu firsatlar ve tasarıma dayalı anlamlandırma olarak belirlenmiştir. Etkinlikler sonunda katılımcıların program liderliği kavramına yönelik farkındalıklarının belirgin şekilde arttı̆̆ gözlenmiştir.

Anahtar kelimeler: Ĕ̆itim programı liderliği, currere yöntemi, otobiyografi, sosyal sorumluluk, çă̆ın sunduğu firsatlar

\section{A Study on Curriculum Leadership Competencies}

\begin{abstract}
:
This research, it is aimed to improve the knowledge, skills, and competencies of teachers and educators as curriculum leader. The participants of the research, which was carried out with the before-and-after study design, were determined by using the purposeful sampling model. Twenty participants were selected from teachers, education administrators, lecturers, and graduate students studying or working in different universities. In the research, firstly, the opinions and evaluations of the participants before the training activity were taken. Afterward, in the scope of curriculum leadership, fifty-five hours of scientific training activity and application studies were presented to the participants. Finally, the post-situation views and evaluations of the participants were taken. The collected data were presented as themes, categories, and codes by using descriptive analysis. Based on the findings; Two themes were reached before the training activity (pre-situation). These are; social sensitivity and social responsibility competence, awareness of the opportunities offered by the age, and the competence to benefit. After the training activity (post-situation), it was determined that the emerging themes were currere method, social responsibility, opportunities of the age, and understanding by design. At the end of the activities, it was observed that the awareness of the participants towards the concept of curriculum leadership increased significantly.
\end{abstract}

Keywords: Curriculum leadership competencies, currere method, autobiography, social responsibility, opportunities offered by the age

* Sorumlu Yazar -mail: oktayakbas@hotmail.com

ORCID No: 0000-0001-7252-0660

** Bu çalışma TUBİTAK BİDEB 2237-A programı kapsamında desteklenen 1129B371901386 numaralı "Eğitim Programı Liderliği Becerilerinin Geliştirilmesi Kursu'ndan üretilmiştir. 


\section{GÍRIŞ}

Eğitim faaliyetlerinin planlanması ve uygulanması süreci, eğitim programı çalışmaları kapsamındadır. Eğitim programları ile farklı kademelerde eğitim alan 18 milyon öğrencinin (MEB, 2020) yılda yaklaşık 1000 saati planlanmaktadır. "Hangi bilgi, beceri ve yeterlilikler değerlidir?" sorusu güncelliğini korumakta ve eğitimle ilgili tartışmaların odağında kendine yer bulmaktadır. Bu soruya verilecek isabetli cevaplar ile toplum ve birey için faydalı konulara odaklanma sağlanabilir. Bir bilimsel alan olarak eğitim programı çalışmalarında da yeni model ve yaklaşımlar ortaya çıkmaktadır. Tyler (2014) ve Ertürk'ün (2013) açık, anlaşılır, rasyonel ve kontrol edilebilir modellerinin geçerliliğini korumaya devam etmesinin yanında, eğitim programları alanına yönelik eleştirel bakış, sosyokültürel duyarlılık, dezavantajlı öğrencilerin bulunduğu okullara yönelik zenginleştirilmiş farklı öğretim programları hazırlanması talebi devam etmektedir. Öğrenene okulda ve okul dışında planlanmış etkinlikler yoluyla sağlanan öğrenme yaşantıları düzeni anlayışına (Varış, 1996) ek olarak eğitim programı, bir risk alma, zihinsel, ahlaki meydan okuma, özgürlük ve firsat programı (Ellis, 2015) olarak da görülmeye başlanmıştır.

Eğitim programı liderliği çalışmalarında, eğitim programı, liderlik ve öğretim çalışmaları eklektik olarak birleştirilmektedir (Henderson, 2014). Bu ise eğitim programı liderleri olarak öğretmen ve eğitimcilerde yeni yeterliliklere ihtiyaç duyulacağının göstergesidir. Sınıfa etki eden toplumsal sorunların çözümü için rol olma, öğrenme liderliği, anlamlandırmayı sadece konu olarak görmeyen aynı zamanda bireysel ve sosyal olarak gören 3S anlayışı, eğitsel otobiyografi ve currere yöntemi öne çıkmış program liderliği anlayışının bazı alt kavramlarıdır. Sorunlara acil çözüm bulma ihtiyacının/baskısının da etkisi insanları liderlik anlayışına yönlendirir. Eğitim araştırmalarında liderlik konusunun yoğun çalışılması liderlerin eğitimdeki bu krizleri çözecek anahtar kişi olarak görülmelerindendir (Pinar, 1994). Bu araştırmalarda dikkat edilmesi gereken liderliğin iyi tanımlanmasından çok, iyi liderliğin tanımlanmasıdır (Henderson, 1998). Bir taraftan, farklı kültürlerin kaynaşması, göçmenler, sosyal tabakalar, ekonomik problemler, siyasi gelişmeler diğer taraftan ulaşılması gereken hedefler, değişen öğretim materyalleri, sınıf yönetimi, idari faaliyetler, yetersiz kaynaklar düşünüldüğünde eğitimcilerin krizlerle iç içe geçmiş bir hayatı olduğu inkâr edilemez. Bolman ve Deal (2017) bireyi, ilişkileri ve bağlamı merkeze alan liderlik anlayışının önem kazandığını vurgulamıştır. Eğitim program liderliği kavramı da bir bakıma bu anlayışın eğitim ortamlarına yansımasıyla ortaya çıkmıştır.

Eğitim programı, tüm öğrencilerden öğrenmelerini ve hatırlamalarını istediğimiz gerçeklerden, detaylardan ve becerilerden oluşan durağan bir olgu değildir. Aksine belirli bir disiplinde öğrencilerin; önceki bilgileri, ilgileri ve deneyimleri ile temel kavram, ilke, beceri, alışkanlık ve uygulamalar arasında güçlü ve çeşitli bağlantılar kurmalarını sağlayacak dinamik bir tasarım sürecidir (Tomlinson ve diğerleri, 2017). "Okul ne yapar?" sorusuna cevap arayan araştırmaların asıl odak noktası eğitim programlarıdır. Eğitim programlarının öğrenciye etkisi yönüyle yaşamla ilgili firsatlar ve engeller bağlamında değerlendirdiğimizde liderliğin diğer alanlarda olduğu gibi eğitimde de neden gerekli olduğu anlaşılır (Mackenzie, 1949). Mackenzie (1949) program liderlerinin, bireye değer verme, sosyal yaşam kalitesini artırma, öğrenme özgürlüğü sağlama, temel değerlerde birlik sağlama ve hedeflere doğru ilerleme, başlıkları üzerinde düşünmesi ve bu konularla ilgili planlamalar yapması gerektiğinden bahsetmektedir. Her bir başlık, program liderinin planlarında ve uygulamalarında dikkate alması gereken alanlar olarak değerlendirilebilir. Bu bağlam içerisinden öğretmenlerin daha etkin olacağ 1 , bizzat sorumluluk üsteleneceği bir anlayışı geliştirmek gerekir. Program liderliği bu konuda 
uygulanan sisteme farklı bir bakış açısı sunarak katkı sunabilir. Henderson (2010) program liderliğini şu şekilde açıklamıştır:

Program liderliği, yenilikçi program çalışmalarını güçlendirmeyi merkezine alır. Bu anlayışta öğretim; eğitim felsefesini, politikalarını, standartlarını ve hedeflerini kavramsallaştırma; programı tasarlama; plan ve uygulama sürecinde koordinasyonu sağlama; kapsamlı değerlendirmeler hazırlama ve çalışma kültürünü düzenleme gibi çok daha geniş ekolojik bir çerçeve içerisinde değerlendirilir.

Program liderliği katkı sunduğu çerçeve açısından; inançlardaki değişim ve yapısal yenilik olmak üzere iki farklı perspektiften yorumlanmıştır (Hawthorne ve Henderson, 2000; Hsieh, Tseng ve Chen, 2021). İnançlardaki değişim, program liderliğinin demokratik yönünü ve okulun bir parçası olan herkese değer vermeyi vurgular. Program liderlerinin, yansıtıcı keşifler yapmaları, cinsiyet, sınıf, diğer kişisel ve toplumsal durumlarla ilgili sürekli araştırmayı ve keşfetmeyi sürdürmeleri önemli bir boyuttur. Yapısal yenilik ise program liderlerinin, sorunları tanımlamaları, çözümler üzerinde düşünmeleri, yeni bir anlayış geliştirmeleri üzerine yoğunlaşır. Cesaret verme, destekleme, toplumsal farkındalıkları artırma, öğretim yöntemleri üzerinde düşünme, program tasarımlarını, planlamalarını, değerlendirmelerini gözden geçirme ve okul kültürü oluşturma adına yapılan çabaları yansıtır. Eğitim programı liderliği kendi anlamlandırma yolculuğuna yoğunlaşarak akademik bilgi ile kendi yaşam öyküsü arasındaki bağı fark etmeyi (Henderson, 2010), program okuryazarı olmayı ve öğrenme-öğretme sürecini engelleyen sınıf içi ve sınıf dışı problemlere çözüm aramayı kapsamaktadır. Eğitim programı lideri, program hakkında derin bir anlayış geliştirmiş, uygulamaya aktarmış ve öğretim sürecine etki eden sorunlara duyarlı kişiler demektir (Akbaş ve Keskin, 2021).

Eğitim programlarında nasıl yeterlilikler yer bulmuşsa, eğitim programı uygulayıcıları olarak öğretmenler de program yeterliliklerine sahip olmalıdırlar. Yeterlilik kavramı bireyin görevler kategorisini gerçekleştirme veya bir sorun durumlar dizisini çözme amacıyla bilişsel, duyuşsal, devinsel, ilişkisel niteliklerin toplamını harekete geçirme yeteneğidir (Demeuse ve Christine, 2016). Bu süreç, değiştirme, başa çıkma, işi yapma ve problem çözme süreçlerini de kapsamaktadır. Eğitim programı liderlik yeterlilikleri gelişmiş bir öğretmenin öğrenmeöğretme sürecine etki eden sınıf içi ve sınıf dışı problemlerle başa çıkabilmesi gerekir. Bir öğretim programının öğretim sorumluluğunu alan öğretmenler, program uzmanı ya da programın gerektirdiği yeterliliklere sahip olarak nitelendirilebilir. Tablo. 1'de Demeuse ve Christine'den (2016) hareketle uzman ve yeterlilik kavramları karşılaştırılmıştır. Eğitim programı liderliği kapsamındaki lider tanımlamalarında ise Henderson (2010) ve Barth (2001) kullanılmıştır.

Tablo 1. Uzman, Yeterlilik ve Liderlik Özelliklerinin Eğitim Programı Liderliği Kapsamında Karşılaştırılması

\begin{tabular}{|c|c|c|}
\hline Uzman & Yeterlilik Sahibi & Lider \\
\hline $\begin{array}{l}\text { Bir işin ya da mesleğin yerine } \\
\text { getirilmesiyle ilgili bir dizi } \\
\text { durumu özgün ve etkili } \\
\text { çözümler üreterek çözümleme }\end{array}$ & $\begin{array}{l}\text { Bir görevi yerine getirme veya } \\
\text { belirli mesleki bağlamda her türlü } \\
\text { bilgi ve beceriyi işe koşarak bir } \\
\text { sorunu çözme yetkinliği }\end{array}$ & $\begin{array}{l}\text { Sınıfta ve sınıf dışında öğrenmeyi } \\
\text { sınırlayan veya engelleyen } \\
\text { problem durumlarına karşı çözüm } \\
\text { yolları aramak }\end{array}$ \\
\hline $\begin{array}{l}\text { En güncel sorun durumlarını } \\
\text { bocalamadan, uzun uzadiya } \\
\text { düşünmeden hizlıca }\end{array}$ & $\begin{array}{l}\text { Yeterlilik kavramı bireyin bir } \\
\text { görevler kategorisini gerçekleştirme } \\
\text { veya bir sorun durumlar dizisini }\end{array}$ & $\begin{array}{l}\text { Konuyu anlamlandirma sürecine } \\
\text { ek olarak bireysel ve sosyal } \\
\text { anlamlandırma birlikte ele alma }\end{array}$ \\
\hline
\end{tabular}

altına alma

çözme amacıyla bilişsel, duyuşsal, devinişsel, ilişkisel niteliklerin toplamını harekete geçirme yeteneği 
Başkalarının nasıl yapacağını bilmediği durumları yapabilme

Yaptıklarını en güvenilir, en ekonomik ve en şık şekilde yapabilme
Yeterlilik bir bilgi sistemini harekete geçirerek ve uygulayarak bazı durumlarla başa çıkabilme yeteneği

Bilgiler ve beceriler bütününü bir karmaşı sorun durumlar kategorisini çözme amacıyla harekete geçirme işi
Öğrencilerin sosyal ve akademik gelişimine daha fazla katkı sağlayacağ1 ve sosyal duyarlılı̆̆ artırarak eğitim problemlerinin çözümünde daha etkin olma

Tüm sistemi etkileyen eğitim problemlerinin çözümünde eleştirel, sorumluluk sahibi, bilgelikle ve katılımcı olarak rol alma

Uzmanlık, başkalarının nasıl yapılacağını bilmediği durumlara ilişkin bilgi ve beceriyi, en güncel sorun durumlarında bocalamadan hızlıca kontrol altına almayı ve en güvenilir, en ekonomik ve estetik şekilde yapmayı vurgularken; yeterlilik bireyin bir görevler kategorisini veya birtakım sorunları çözme amacıyla bilişsel, duyuşsal, devinişsel, ilişkisel niteliklerin toplamını harekete geçirme işine ve ve sorunlarla başa çıkmaya odaklanılmaktadır. Liderlikte ise benzer bir şekilde problem durumlarına yönelik çözüm vardır. Problem durumlarının tanımlanmasında sosyal, kültürel ve ekonomik boyut dikkate alınır ve çözümünde konuyu anlamlandırmaya ek olarak sosyal, bireysel anlamlandırmanın işe koşulması önerilir. Karşılaştırmayı temel alarak, yeterlilik sahibi eğitim programı lideri; sınıfta ve sınıf dışında öğrenmeyi sınırlayan veya engelleyen problem durumlarının çözümünde bilişsel, duyuşsal, devinişsel, ilişkisel ve bireysel niteliklerin toplamını harekete geçirme yetisine sahip kişi olarak tanımlanabilir. Bu çalışmada eğitim programı liderliği yeterlilik alanları, currere yöntemi, sosyal sorumluluk, çağın sunduğu firsatlar ve tasarım yoluyla anlamlandırma başlıklarında toplanmıştır.

\section{Ĕ̆itim Programı Liderliği Yeterlilik Alanları}

Sokrates en değerli bilginin insanın kendi öz varlığına ilişkin bilgi olduğunu vurgulamış, bunu kendine ilke haline getirmiş ve "kendini tanı" olarak ifade etmiştir (Hilav, 2019). Currere yöntemi bir bakıma bu kendini tanı ifadesinin yansımasıdır. Pinar (1994)'ın dört aşamalı bir yapı olarak çerçevesini çizdiği Currere yöntemi geçmiş deneyimleri, gelecek planlamaları, şimdinin yansımaları ve bu üç aşamanın sentezlenmesini içeren bir anlayıştır. Birey bu dört aşama ile kendi öz deneyimlerine odaklanır, eğitim tecrübelerini düşünür, yaşam deneyimlerini değerlendirir, geleceği hayal eder, hedeflerini ve planlarını gözden geçirir ve yorumlar. Sonuçta kendi öznel dünyasını farklı açılardan deneyimler ve kendine yol haritası çizer. Geçmiş, gelecek ve şimdinin arasında kurulan bu bağ bireyi güçlendirir, ufkunu genişletir. Kendini daha iyi tanıyan bir eğitimcinin ortaya çıkmasına katkı sunar. Öğrenme olmadan öğretme yoktur diye vurgulayan Freire (2019) öğretmenlerin sürekli olarak öğretilenler üzerinde yeniden düşünmeye ve kendi pozisyonlarını gözden geçirmeye devam etmelerinin öneminden bahsetmiştir. Otobiyografik bir yöntem olan currere, bireyin yaşam hikâyesi ile öğrenme deneyimi arasındaki bağlantıyı daha açık hale getirmek için de kullanılır (Henderson, 2014).

Eğitim programı kısa ve uzun vadedeki etkileri ile toplumsal yapının gelişmesinde ve güçlenmesinde pay sahibi olduğu için bir program liderinin sosyal sorumluluklarının farkında olması ve çevresini de yönlendirmesi gerekir. Öğrenme-öğretme sürecine etki eden sosyal sorunlara yönelik farkındalık ve çözümü için sorumluluk alma ve gönüllü çalışmalar organize etme ulaşılması gereken hedeflerdendir. Liderlik bir mevki, makam değil sürekli hareket halinde olma halidir (Bolman ve Deal, 2017). Yani aktif olma halidir. Bu yönüyle program liderlerinin planladıkları faaliyetleri, etkinlikleri sınıf ortamının da dışarısına çıkarmaları beklenmektedir. Bu aşamada karşımıza sosyal sorumluluk çalışmaları çıkmaktadır. Giderek artan sayıda eğitim kurumu hem topluma karşı sosyal sorumluluklarını yerine getirmeye 
çalışmakta hem de öğrencilerini çevrelerine ve topluma duyarlı bireyler olarak yetiştirmektedir. Hizmet ederek öğrenme (Service Learning), topluma hizmet (Community-service), gönüllü hizmetler (Volunteer Service) çalışmaları hem bir öğretim yöntemi olarak tasarlanmış hem de toplumsal sorumluluklar geliştirmek amacıyla kullanılmaktadır. Gönüllük çalışmaları da bu kapsamda değerlendirilebilir. Gönüllülük faaliyetlerinin ortak özelliği toplumsal hayata katkıda bulunmayı sağlayan bir faaliyet olmasıdır (Yurttagüler, 2020) Gönüllü kişi kendisi ile ilişkisi bulunmayan üçüncü bir kişinin yararına faaliyette bulunur. Doğrudan bir kişinin yararlanmadığ 1 faaliyetler toplumsal fayda için de yürütülebilir (Doğan-Yenisey, 2020).

Her dönem kendi içinde firsatları ve tehditleri beraberinde getirir. Doğru planlama ve yerinde müdahaleler çoğu zaman kazançlı çıkmaya imkân verir. Özellikle eğitimciler için kendi bulundukları çağın gerekliliklerini herkesten önce kavramak ve her şeye rağmen öğrenme ortamında uygulamaya geçirebilmek çok önemlidir. Bu gereklilikler bazen 1830'lu yıllarda Başhoca İshak Efendi'nin yaptığı gibi sınıfa kara tahta temin etmek (Akbaş, Taş, Duman ve Keskin, 2018; İhsanoğlu, 2000) olabileceği gibi bazen de günümüzde uygulamada olduğu şekliyle farklı dijital araçlar kullanarak çevrimiçi öğretim yapmaya devam etmek şeklinde de olabilir. Eğitimciler var olan fiziksel ve toplumsal çevreleri nasıl kullanabileceklerini ve bu çevrelerin işe yarar deneyimler oluşturma için sunduklarını nasıl çıkarıp alabileceklerini bilmelidirler (Dewey, 2013). Dewey'in vurguladığı bu durumu bir eğitimcinin çevresinde olup bitenlerle, çağının kendisine sunduklarıyla yakından ilgili olması olarak da yorumlanabilir. Dijital öğrenme firsatları, etkileşimi artıran sosyal medya ortamları ve eğitimde ulusal ve uluslararası destek bulma ve sunmada artan firsatlar eğitim programı liderliğinin önemli bir boyutu olarak görülmektedir.

Herhangi bir şey için en uygun zaman, uygun durum veya şart (Türk Dil Kurumu, 2020) olarak tanımlanan firsat uygun duruma vurgu yapmaktadır. Öncelikle, öğretmenler özellikle ailesinde lisans eğitimi almamış öğrenciler için bir fırsattır. Fırsatlar gözden geçirilirken çağın sunduğu firsatlara, sosyal çevrenin sunduğu firsatlara ve araç-gereçlere yoğunlaşmak fayda sağlayabilir. Fark olağanüstü yeteneklerde midir? Yoksa onlara sunulan olağanüstü firsatlarda mıdır? Malcolm Gladwell "Çizginin Dışındakiler" isimli kitabında başarıyı yetenek, zekâ ve çabaya değil, zamanın ve çevrenin sunduğu olağanüstü firsatlara, gizli avantajlara ve kültürel mirasa bağlamakta ve öğrenmeyi, gelişmeyi sağlayan ekolojiye vurgu yapmaktadır (Gladwell, 2019). Toplumun çocuklar ve gençler için eşit fursatlar sunması, fırsatlardan haberdar etmesi ve fırsatlardan faydalanması için teşvik edilmesi gerekir. Fırsat oluşturma ise bir başka alt başlıktır. TÜBİTAK, Erasmus projeleri öğrencilere ve öğretmenlere yeterlilikler çerçevesini fark etmelerini ve yeni yeterlilikler geliştirmelerini sağlayacak fırsatlar oluşturulabilir. Mobil uygulamalar, birçok üniversitenin sunduğu açık ders materyalleri, çevrimiçi dersler sunan platformlar, eğitsel video ve filmler birçok ders içeriğine yönelik firsatlar sunmaktadır.

Öğretmenler arasında bir programı planlandığı şekilde uygulayabilmek çok nadir rastlanan bir durumdur. Öğretmenler öğrencilere daha anlamlı hale getirmek için bu programları sınıfa uygun hale getirirler (Marsh ve Willis, 2007). Öğretmen bir yandan belirli birey kümelerinin kapasite ve ihtiyaçlarını incelerken, bir yandan da bu ihtiyaçları tatmin edecek ve bu kapasiteleri geliştirecek deneyimlere konu alanı veya içerik sağlayacak koşulları düzenlemek zorundadır (Dewey, 2013). Bu işlem tasarımın etkin kullanılmasına bağlıdır. Freire'e (2019) göre öğretmenlere hazır sunulan eğitim materyalleri sunulduğu gibi kullanıldığında öğretmenlerin yaratıcılıkları ve eleştirel davranmaları engellenir. 
Anlamlandırma eğitim programı liderliği bakış açısında merkezi bir yere sahiptir. Eğitim programları anlamlandırma ve öğrenme yolculuğunun bir parçası olarak görülür. Bu nedenle hem Henderson'da (2010) hem de Wiggins, Wiggins ve McTighe'de (2005) anlamlandirma önemli bir yer tutar. Büyük fikir bu süreçte yol gösterici ve anlamı oluşturmada kritik öneme sahiptir. Anlama, aktarma ile ilgilidir. Bilgimizi ve becerimizi etkin bir şekilde transfer etme, bildiklerini alıp onu yaratıcı, esnek, akıcı bir şekilde, farklı durumlarda ve sorunlarda kendi başımıza kullanma kapasitesini içerir. Bir durum ya da konuyu gerçekten anladığımızda; açıklayabilir, yorumlayabilir, kullanabilir, perspektif içeren bir bakış açısına sahip olur, empatik davranır ve benlik bilgisine sahip oluruz (Wiggins ve McTighe, 2005). Anlamlandırmanın içerik boyutuna ek olarak kişisel ve sosyal boyutunun da olduğu görülmektedir. Buradan hareketle (Henderson, 2010) lider öğrenenlerin konuyu anlamlandırmayı bireysel ve sosyal öğrenme ve kendi uygulamaları ile birleştirebildiklerini ifade etmektedir. Anlamlandırma fikir ve olaylara tarihsel ve kişisel boyut ekleme, bireyin kendi önyargıları ve bakış açılarının farkına varması ve tüm çevreye yönelik olarak demokratik ilkeleri de içine alan- empatik bir bakış açısı geliştirmekle ilgili olduğu görülmektedir.

Anlamaya dayalı tasarım yapan öğretmenler, büyük fikri belirler, neyin değerli olduğuna karar verir ve sorumluluk alabilir. Tasarlama, büyük fikir doğrultusunda sonucu hayal etme, en sonda oluşmasını istediğimiz anlam ve transferden hareketle süreci düzenlemedir (Yurtseven, 2016). Büyük fikirler konunun çekirdeğini oluşturduğu için, ders ya da ünite boyunca öğrencilerin çekirdeğe ulaşabilmeleri adına daha derin düşünmelerine yardımcı olur (Wynn, Wiggins ve Berger, 1997). Burada sözü geçen anlama, derste geçen püf noktaları anlamaktan çok, öğrencinin ders süresince geliştireceği anlam sayesinde bilgiyi gelecekte karşılaşacağı tüm yeni ortamlara uyarlama yeteneği kazanmasıdır. Tasarıma dayalı anlamlandırmanın hedefi, uzak ve genel hedeflerle dersin hedeflerini daha iyi bir şekilde birbirine bağlamaktır (Wiggins ve McTighe, 2005). Wiggins ve McTighe'e (2005) göre otantik zorluklar gerçek durumun fursat ve zorluklarını içerdiğinden öğrencilerin otantik zorluklar ile karşılaştırılmalıdır. Onlara göre anahtar zorlayıcı görevler yetişkinleri işyerinde, sivil hayatta ve kişisel yaşamda test eder. Gerçek meydan okumalar spesifik durumlarda karışıklık ve anlamlı hedefler içerir. Okul testleri bağlam içermez, oysaki gerçek yaşamın karmaşıklığı ve zorluğu okulu aşmaktadır. Henderson (2015) anlamlandırmanın üç boyutundan biri olan sosyal anlamlandırmanın aynı zamanda gerçek yaşam boyutunu içerdiğini belirtmiştir.

Yapılan literatür taramasında, eğitim programı liderliği araştırmalarında; eğitim programı, liderlik ve öğretim çalışmalarının eklektik olarak birleştirildiği görülmektedir. Bu çalışmalarda sınıfa etki eden toplumsal sorunların çözümü için rol olma, anlamlandırmayı sadece konu olarak görmeyen aynı zamanda bireysel ve sosyal olarak gören anlayış, tasarıma dayalı anlamlandırma, çağın sunduğu firsatları fark etme ve currere yöntemi eğitim programı liderliği kavramlarından bazılarıdır. Bu çalışmada eğitim programı liderliği kuramsal yapısından hareketle, 55 saatlik bir bilimsel etkinlik programı TÜBİTAK 2237-A proje kapsamında planlanmış ve uygulanmıştır. Çalışmanın eğitim programı liderliği kavramının Türkçe literatüre kazandırılmasına, açıklanmasına ve uygulanmasına rehberlik etme konularında katkı sağlayacağı düşünülmektedir.

\section{Araştırmanın Amacı}

Araştırmanın amacı, eğitim programlı liderliği yeterliliklerini geliştirmeyi amaçlayan eğitim etkinliği ve faaliyetlerinin, farklı eğitim bilimleri alanlarında lisansüstü eğitim alan katılımcıların eğitim programı liderlik anlayışlarındaki değişmeyi ve farkındalığı belirlemektir. 


\section{YÖNTEM}

\section{Araştırma Modeli}

$\mathrm{Bu}$ araştırma durum öncesi-sonrası araştırma deseni ile planlanmıştır. Test öncesi-test sonrası desen olarak da adlandırılan bu desen, bir olguda, konuda, durumda veya tutumdaki değişimleri ölçmek için kullanılan bir tasarımdır. Bir eğitim etkinliğinin/programının etkisini ve etkililiğini ölçmek için kullanılan en uygun araştırma desenidir. Bu desenle tasarlanan araştırmalarda, bir olgudaki veya değişkenlerdeki değişimi anlayabilmek için aynı çalışma grubundan iki farklı zamanda veri toplanır (Şekil 1). Bu iki veri arasındaki farklar/değişimler karşılaştırılır. Elde edilen sonuçlar eğitim etkinliğinin/programının katkısı olarak yorumlanır (Kumar, 2015). Eğitim programı liderliği becerilerinin geliştirilmesi amacıyla çalışma grubuna uygulanan ön değerlendirme, eğitim programının uygulanması ve aynı çalışma grubuna uygulanan son değerlendirme ile eğitim etkinliği ve faaliyetlerinin katılımcılar üzerindeki etkisini ölçmek, eğitim programının çalışma grubundaki bireylerin bilgi, beceri ve yeterliliklerindeki değişimi ortaya koymak amaçlandığından bu çalışmada durum öncesisonrası araştırma deseni tercih edilmiştir.

Şekil 1. Durum Öncesi-Sonrası Araştırma Deseni (Kumar, 2011, s. 108)

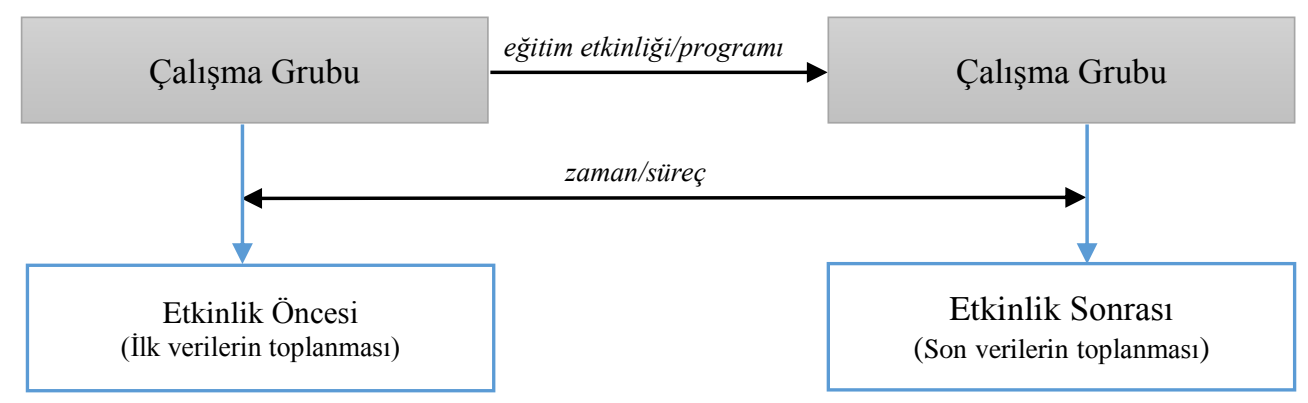

\section{Çalışma Grubu}

Araştırmanın çalışma grubunun belirlenmesinde amaçlı örnekleme modelinden yararlanılmıştır (Christensen, Burke Johnson ve Turner, 2015; Patton, 2014). Amaçlı örnekleme belli ölçütleri karşılayan veya belli özelliklere sahip olan bir veya daha fazla özel durumlarda çalışılmak istendiğinde tercih edilir (Büyüköztürk, Kılıç Çakmak, Akgün, Karadeniz ve Demirel, 2012). Bu yönüyle amaçlı örnekleme modellerinden biri olan maksimum çeşitlilik örneklemesinden yararlanılmıştır. Maksimum çeşitlilik örneklemesi ile eğitim programı liderliği yeterliliklerini geliştirmek isteyen veya akademik / mesleki hayatında bu konuyu çalışmayı düşünen öğretmen, eğitim yöneticisi, öğretim elemanı ve lisansüstü eğitime devam eden öğrencilerden oluşan bir çalışma grubuna yer verilmesi amaçlanmıştır. Aynı zamanda katılımcıların farklı üniversitelerde eğitim gören veya çalışan, eğitim fakültesinin farklı programlarından mezun olan gönüllüler arasından seçilmesine özen gösterilmiştir. Böylelikle araştırmanın çalışma grubunu oluşturan 20 katılımcı arasında bölüm ve üniversite çeşitliliği sağlanmıştır. Diğer taraftan çalışma grubunda yer alan 20 katılımcıdan ikisi yabanc1 uyruklu öğrenci statüsünde Türkiye'de lisansüstü eğitimine devam etmektedir. Çalışma grubunda yer alan katılımcılara ilişkin ayrıntılı bilgiler Tablo 2'de sunulmuştur.

Tablo 2. Araştırmanın Çalışma Grubunda Yer Alan Katılımcıların Eğitim ve Çalışma Durumları

\begin{tabular}{|c|c|c|c|c|}
\hline Kod & Cinsiyet & Mezun Olduğu Lisans Programı & $\begin{array}{l}\text { Lisansüstü Eğitim } \\
\text { Durumu }\end{array}$ & Mesleği \\
\hline $\mathrm{K}_{1}$ & Erkek & Sınıf Öğretmenliği & Yüksek Lisans & Proje Koordinatörü \\
\hline
\end{tabular}




\begin{tabular}{|c|c|c|c|c|}
\hline $\mathrm{K}_{2}$ & Kadın & Okul Öncesi Öğretmenliği & Yüksek Lisans & Öğretmen \\
\hline $\mathrm{K}_{3}$ & Erkek & Sosyal Bilgiler Öğretmenliği & Yüksek Lisans & Öğretmen \\
\hline $\mathrm{K}_{4}$ & Kadın & Fen Bilgisi Öğretmenliği & Yüksek Lisans & Öğrenci \\
\hline $\mathrm{K}_{5}$ & Kadın & İngilizce Öğretmenliği & Yüksek Lisans & Öğretmen \\
\hline $\mathrm{K}_{6}$ & Erkek & Bilgisayar Öğretmenliği & Yüksek Lisans & Öğretmen \\
\hline $\mathrm{K}_{7}$ & Kadın & Psikolojik Danışmanlık ve Rehberlik & Yüksek Lisans & Öğretmen \\
\hline $\mathrm{K}_{8}$ & Kadın & Matematik Öğretmenliği & Doktora & Öğretmen \\
\hline $\mathrm{K}_{9}$ & Kadın & Beden Eğitimi ve Spor Öğretmenliği & Doktora & Öğretim Görevlisi \\
\hline $\mathrm{K}_{10}$ & Kadın & Fizik Öğretmenliği & Doktora & Öğretim Görevlisi \\
\hline $\mathrm{K}_{11}$ & Kadın & Psikolojik Danışmanlık ve Rehberlik & Yüksek Lisans & Öğretmen \\
\hline $\mathrm{K}_{12}$ & Erkek & Sinıf Öğretmenliği & Yüksek Lisans & Proje Koordinatörü \\
\hline $\mathrm{K}_{13}$ & Erkek & Aile Ekonomisi ve Beslenme Eğitimi & Yüksek Lisans & Öğretmen \\
\hline $\mathrm{K}_{14 \text { (Yabancı }}$ & Kadın & Psikolojik Danışmanlık ve Rehberlik & Yüksek Lisans & Öğrenci \\
\hline $\begin{array}{l}\text { Uyruklui) } \\
\mathrm{K}_{15}\end{array}$ & Erkek & Sosyal Bilgiler Öğretmenliği & Yüksek Lisans & Öğrenci \\
\hline $\mathrm{K}_{16}$ & Kadın & İngiliz Dili Eğitimi & Doktora & Araştırma Görevlisi \\
\hline $\mathrm{K}_{17}$ & Erkek & Sinıf Öğretmenliği & Yüksek Lisans & Öğretmen \\
\hline $\mathrm{K}_{18}$ & Kadın & Okul Öncesi Öğretmenliği & Yüksek Lisans & Öğretmen \\
\hline $\begin{array}{l}\mathrm{K}_{19 \text { (Yabancı }} \\
\text { Uyruklu) }\end{array}$ & Kadın & Yabancı Diller Eğitimi & Doktora & Öğretim Görevlisi \\
\hline $\mathrm{K}_{20}$ & Kadın & Fen Bilgisi Öğretmenliği & Yüksek Lisans & Öğrenci \\
\hline
\end{tabular}

\section{Durum: Bilimsel Ĕgitim Etkinliği Süreci}

$\mathrm{Bu}$ çalışmada durum, eğitim programı liderliği kavramına ait çerçevenin ortaya çıkarılması ve öğretmenlerin program liderliği ile ilgili değerlendirmelerinin bilimsel eğitim etkinliği doğrultusunda değişimidir. Çalışma grubunda bulunan katılımcılara yönelik olarak planlanan 55 saatlik bilimsel eğitim etkinliklerinde yedi farklı üniversiteden 12 öğretim üyesi görev almıştır. Yüz yüze yapılması planlanan eğitimler salgın koşulları nedeniyle çevrimiçi olarak 5-12 Nisan 2021 tarihinde gerçekleştirilmiştir. Eğitim etkinliklerine ve uygulama çalışmalarına \%70 oranında katılım zorunlu tutulmuş bunu sağlayamayan beş katılımcının sonuçları değerlendirmeye alınmamıştır. Verilen eğitimlerin uygulama etkinlikleri için, yapılan çalışmaların amacına uygun olacak şekilde gruplar oluşturulmuş ve grupların birlikte çalışmalarını sağlamaya yönelik çevrimiçi odalar kullanılmıştır. Her uygulama çalışması süresince eğitmenler, aralıklarla bu odaları ziyaret ederek yapılan çalışmalarla ilgili bilgi almış ve dönütler vermişlerdir. Ayrıca iki yardımcı personel sürekli olarak sistemde aktif bir şekilde bulunmuş ve grupların uygulama etkinlikleri ile ilgili ihtiyaçları giderilmiştir. Tamamlanan etkinlikler sonunda değerlendirmeler çalışma grubunun tamamıyla beraber yapılarak daha kalıcı bir öğrenme hedeflenmiştir. Eğitimler sonunda elde edilen ürünler ve hazırlanan materyaller bütün çalışma grubu ile paylaşılmıştır.

\section{Veri Toplama Aract}

Araştırmada kullanılan veri toplama araçları, araştırmacılar tarafından geliştirilen görüşme formlarından ve katılımcıların yansıtıcı günlüklerinden oluşmaktadır.

Görüşme formları, eğitim programı öncesinde ve sonrasında kullanılmak üzere iki farklı form şeklinde hazırlanmıştır. Bu nedenle görüşme formlarında yer alan her soru birbirine paralel nitelikte ve karşılaştırılabilir içeriktedir. Görüşme formları, katılımcıların program boyunca edindikleri bilgi, beceri ve yeterlilikleri ortaya koymayı amaçladığı için açık uçlu olarak 10 soru şeklinde hazırlanmıştır. Açık uçlu sorularla hazırlanan görüşme formları ile katılımcıların eğitim programı liderliği hakkındaki görüşlerini ve deneyimlerini sınırlamadan ifade etmesi amaçlanmıştır (Creswell, 2017). Görüşme formlarının hazırlanmasında; görüşme sorularının araştırmacılar tarafından hazırlanması, görüşme formlarının uzman görüşleri ile değerlendirilmesi, görüşme sorularının yeniden düzenlenmesi, pilot uygulamanın yapılması, 
görüşme formlarının veri toplama aracı olarak son düzenlemelerinin gerçekleştirilmesi adımları takip edilmiştir. Bu süreçte bir ölçme ve değerlendirme alan uzmanı ve bir eğitim bilimleri alan uzmanının uzman görüşünden yararlanılmıştır. Veri toplama sürecine başlamadan önce görüşme sorularının geçerliğini sağlamak için pilot görüşmeler tamamlanmıştır. Görüşme formlarında yer alan ifadelere ilişkin gerekli durumlarda katılımcı teyidine de başvurulmuştur. Aynı zamanda araştırmanın tüm süreçleri ayrıntılı şekilde raporlandırılmıştır. Araştırmada veri toplama ve analizi sürecinde birden fazla araştırmacının yer alması da güvenirlik önlemlerinden biri olarak gerçekleştirilmiştir (Yıldırım ve Şimşek, 2013, s. 289-298).

Araştırmanın diğer veri toplama aracını oluşturan günlükler ise altı günlük eğitim boyunca her gün katılımcılar tarafından oluşturulmuştur. Günlüklerin yazımında herhangi bir yönlendirici ifade ya da soruya yer verilmemiştir, yalnızca eğitim programı boyunca edindikleri bilgi ve deneyimi nasıl anlamlandırdıklarını ifade etmeleri istenmiştir. Araştırmada veri toplama araçlarında çeşitlilik sağlanarak da çalışmanın geçerlik ve güvenirliğine katkıda bulunmak amaçlanmıştır. Bunun yanında araştırmada amaçlı örneklem yönteminin tercih edilmesi, verilerin analiziden ayrıntılı betimleme yapılması da araştırmanın geçerliğini artırmaya yönelik alınan tedbirlerdendir (Y1ldırım ve Şimşek, 2013, s. 304-305).

\section{Verilerin Toplanmast}

Görüşme formları ve günlükler araştırmacılar tarafından Google Form uygulaması ile hazırlanmıştır. Eğitim programı öncesinde görüşme formlarının erişim adresi katılımcılara iletilmiş ve doldurmaları istenmiştir. Elde edilen veriler araştırmacılar tarafından kaydedilmiştir. Eğitim programı sonunda programın etkisini değerlendirmek amaciyla hazırlanan yeni görüşme formunun erişim adresi katılımcılara yeniden gönderilmiş ve cevaplamaları istenmiştir. Katılımcıların görüşme formlarında verdikleri cevaplar soru bazında araştırmacılar tarafından kaydedilmiştir. Eğitim programı boyunca günlüklerin yazımında, katılımcılara hatırlatmalarda bulunulmuş ve o günkü eğitim deneyimine ilişkin ifadelerini yazması istenmiştir. Bu süreçte her katılımcının isimsiz olarak günlükleri doldurmasına özen gösterilmiştir. Katılımcıların günlük kayıtları, her gün araştırmacılar tarafından kaydedilmiştir.

\section{Verilerin Analizi}

Görüşme formları ve günlüklerden elde edilen verilerin analizinde betimsel analizden yararlanılmıştır. Betimsel analiz ile elde edilen veriler, araştırma öncesinde belirlenen kod ve temalara göre tanımlanmaktadır. $\mathrm{Bu}$ süreçte verilerin analizi dört aşamada gerçekleştirilmektedir. Bu aşamalar ve araştırmada yapılan işlemler şunlardır (Yılldırım ve Şimşek, 2013);

- Betimsel analiz için çerçeve oluşturma: Araştırmacılar tarafindan yapılan literatür taramasına ve araştırmada kullanılan veri toplama araçlarına dayalı olarak analiz çerçevesi hazırlanmıştır. Bu çerçeve içinde kod, kategori ve temalar belirlenmiştir.

- Tematik çerçeveye göre verilerin işlenmesi: Araştırmacılar tarafından hazırlanan kodlama çerçevesine göre katılımcilardan toplanan veriler durum öncesi ve durum sonrası olarak düzenlenmiştir. Düzenlenen veriler kodlama çerçevesine uygun olarak araştırmacılar tarafindan ayrıntılı okunmuş ve katılımcı ifadelerine en uygun kod, kategori ve tema altında işlenmiştir.

- Bulguların tanımlanması: $\mathrm{Bu}$ aşamada araştırmadan elde edilen verilerin kodlama çerçevesi altında tablolar halinde sunulması ve alıntılarla desteklenmesi gerçekleştirilmiştir. 
- Bulguların yorumlanması: Betimsel analizin son aşamasında tanımlanan ve okuyucuya sunulan kod, kategori ve temaların açıklanması ve yorumlanması yapılmıştır. Bu sayede durum öncesi ve durum sonrası ortaya çıkan kodların belirlenmesi ve karşılaştırmasının yapılması amaçlanmıştır.

\section{Geçerlik ve Güvenirlik}

Araştırmanın geçerliğini ve güvenirliğini sağlamak amacıyla, araştırmanın her süreci üç araştırmacı tarafından birlikte sürdürülmüştür. İlk olarak görüşme formlarının hazırlanmasında araştırmacıların dışında bir ölçme ve değerlendirme alan uzmanı ve bir eğitim bilimleri alan uzmanından uzman görüşü istenmiştir. Görüşme formlarının kapsam ve yapı geçerliliğine ilişkin uzman görüşlerine dayalı olarak düzenlemeler yapılmıştır. Araştırmanın veri toplama sürecinde ise Google Form uygulamasından yararlanıldığı için katılımcıların verdikleri cevaplar hiçbir müdahalede bulunulmadan dijital olarak saklanabilmiştir. Araştırmanın veri analizi aşamasında da betimsel analize ilişkin güvenirlik çalışmaları yapılmıştır. Betimsel analiz sürecinde verilerin kodlama çerçevesine uygun kodlanması ve doğru temaların altında yer almasına ilişkin kodlayıcı güvenirliğinden yararlanılmıştır. Kodlayıcı güvenirliğini belirlemek için üç araştırmacı aynı görüşme formunu ve katılımcı günlügünü birbirinden bağımsız olarak analiz etmiştir Analiz sonunda ortaya çıkan kodlar arasındaki uyum \%88 olarak hesaplanmıştır. Kodlayıcı güvenirliği düzeyi \%88 olarak bulunduğu için araştırmanın diğer görüşme ve günlük verileri araştırmacılar tarafından paylaşılarak analiz edilmiştir (Miles ve Huberman, 2015). Bu süreçte her bir araştırmacının yaptığı kodlama, diğer iki araştırmacı tarafindan da kontrol edilerek tablolaştırılmıştır (Miles ve Huberman, 2015). Günlükler ve görüşmelerden elde edilen kodlamalar birbiriyle uyumlu olduğu için birlikte sunulmuştur.

\section{BULGULAR}

$\mathrm{Bu}$ bölümde eğitim etkinliği öncesinde ve sonrasında katılımcılardan elde edilen bulgular durum öncesi ve sonrası olarak iki ayrı başlık halinde sunulmuştur. Katılımcıların günlükleri ve görüşme formlarından elde edilen veriler birlikte değerlendirilerek temalar ve kategoriler oluşturulmuştur.

\section{Eğitim Etkinliği Öncesinde Katılımcılardan Elde Edilen Bulgular}

Araştırmadan elde edilen bulgulara dayalı olarak eğitim etkinliğinden önce katılımcı günlüklerinden ve görüşme formlarından elde edilen veriler Tablo 3 'te sunulan kodlamalar çerçevesinde yer almaktadır.

Tablo 3. Eğitim Programı Öncesinde Katılımcılardan Elde Edilen Bulgular

\begin{tabular}{lll}
\hline Tema & Kategori & Kod \\
\hline & İşbirliği & Meslektaşlar \\
& Girişimcilik & Sorunların çözümünde etkin olma \\
Toplumsal Duyarlılık ve Sosyal & Olumlu Okul İklimi & $\begin{array}{l}\text { İletişime açı olma } \\
\text { Sorumluluk Yeterliliği }\end{array}$ \\
& Sorunlar & $\begin{array}{l}\text { Çözm önerileri } \\
\text { Ülkenin eğitim gerçeklerini tanıma }\end{array}$ \\
& Toplum & Toplumsal ihtiyaçları göz önünde \\
& & bulundurma
\end{tabular}


Çağın Sunduğu Fırsatlara Yönelik Farkındalık ve Yararlanma Yeterliliği
Dünyayı Tanıma

Güncellik

Dijital Araçlar
Diğer ülkelerdeki eğitim uygulamaları

21. yüzy1l becerileri

Eğitim uygulamaları/yöntem ve teknikleri Yeniliklerden haberdar olma

Katılımcılara sunulan eğitim programından önce elde edilen bulgular iki tema altında yer almıştır. Bu temalar; toplumsal duyarlılık ve sosyal sorumluluk yeterliliği ile çağın sunduğu fırsatlara yönelik farkındalık ve yararlanma yeterliliği şeklinde belirlenmiştir. Toplumsal duyarlılık ve sosyal sorumluluk teması altında iş birliği, girişimcilik, olumlu okul iklimi, sorunlar ve toplum kategori altında katılımcı ifadelerine rastlanmıştır. Bu kategorilerle ilişkili olarak yapılan kodlamalarda katılımcıların meslektaşlarıyla işbirliği içinde çalışmaya önem verdikleri belirlenmiştir. Katılımcı ifadelerine dayalı olarak eğitim programı liderinin sahip olması gereken yeterlilikler sosyal sorumluluk kavramıyla yakından ilişkilidir. Katılımcılara göre; kendini, mesleğini, meslektaşlarını önemseyen; içinde bulunduğu toplumun sorunlarına duyarlı olan ve çözüm üreten eğitimciler eğitim programı lideri özelliği sergilemektedir. $\mathrm{Bu}$ süreçte hem öğrencileriyle hem meslektaşları olan öğretmenlerle iletişim kurmak, aynı zamanda içinde bulunduğu eğitim ortamını yakından tanımak önemli görülmektedir. Öğrencilerin ve eğitim ortamının ihtiyaçları ile toplumsal ihtiyaçları ilişkilendirebilen, yenilikçi ve yaratıcı bakış açısı sunabilen, üretken bireylerin eğitim programı lideri olabileceği vurgulanmıştır. Aynı zamanda eğitim programı liderinin gönüllü çalışmalarda yer almasının önemi ve gönüllü projelerde sorumluluk almasının gereği üzerinde durulmuştur. Toplumsal duyarlılık ve sosyal sorumluluk yeterliliği altında yer alan katılımcı ifadelerinden bazılarına aşağıda yer verilmiştir.

“Öğrenme çabasında olan bireylere ve meslektaşlarına sosyal yönünün gücüyle rehberlik etmesi gerekir. Gönüllülük kavramını da göz önüne alırsak bir çocuğu yetiştirme bütün toplumun görevidir. Bu sürece liderlik yaparak sorumluluk alan ve gönüllü olarak bir çalışma yapması gereken de eğitim programı lideridir." ( $\mathrm{K}_{20}$, Kadın, Okul Öncesi Öğretmenliği)

“Öğretmenler toplumsal bütünleşmeyi sağlayan topluma yön veren kişilerdir. Ĕ̆itim programı lideri olan ögretmen toplum merkezli konulara eğilim göstererek hem ögrencilerin ögrenmesini să̆larken hem de okulu öğrenen birey ve toplum arasında bir köprü olarak kullanır. Ögretmenler yaşadı̆̆ ç̧evrede sorunları fark edebilen bunlara çok yönlü çözümler üretebilen kişilerdir. Sosyal duyarlılığı yüksek bireyler gönüllü çalışmalarda rol alarak toplumsal gelişmelere katkıda bulunurlar." ( $\mathrm{K}_{7}$, Kadın, Rehberlik ve Psikolojik Danışma)

Eğitim etkinliği öncesi katılımcılardan elde edilen bulgularla ortaya çıkan diğer tema, çağın sunduğu fırsatlara yönelik farkındalık ve yararlanma yeterliliği başlığı olmuştur. Bu tema altında dünyayı tanıma, güncellik ve dijital araçlar kategorilerinde ifadelere rastlanmıştır. Katılımcılara göre eğitim programı liderinin sahip olması gereken yeterliliklerden diğeri içinde bulunduğu dönemi tanımak, dönemin sunduğu firsatların farkında olmak ve bu firsatlardan yararlanmakla ilgilidir. Bu kapsamda katılımcılar eğitim programı liderinin içinde bulunduğu toplumla birlikte dünyayı da tanıması gerektiğini belirten ifadelere yer vermişlerdir. Bu anlamda eğitim programı lideri olmak demek, hem toplumun hem dünyanın eğitimini yakında takip etmeyi gerektirmektedir. Farklı eğitim uygulamalarını ve yenilikçi öğretim yöntemlerini araştırmak, öğrenmek ve uygulamak için değişimin farkında olmak eğitim programı liderinin 
sorumluluklardan biri olarak kabul edilmiştir. Aynı zamanda eğitimde dijital dönüşümün gerektirdiği bilgi, beceri ve yeterliliklerin farkında olması gereken eğitim programı lideri yenilikleri yakından takip etmekle sorumludur. Bu çerçevede çağın sunduğu firsatlara yönelik farkındalık ve yararlanma yeterliliği teması altında yer alan katılımcı ifadelerinden bazılarına aşağıda yer verilmiştir.

"Sosyal medya (dijital dünya) dünya ile gerçek zamanlı iletişim kurabildiğimiz ve gelişmeleri takip edebildiğimiz bir araçtır. Bu araçların eğitim programı lideri tarafindan kullanılarak güncel öğretim yaklaşımlarının takip edilmesi ve yaygınlaştırılması amacıyla kullanılması gerektiğini düşünüyorum.” ( $\mathrm{K}_{4}$, Kadın, Fen Bilgisi Öğretmenliği)

"Ĕ̆itim programı lideri, eğitimin en temel ögelerinden biri olan programin temel yetkilisi olarak tabii ki uluslararası düşünmeli, etkileşim kurmalı, araştırmalarını yapmalı ve tüm dünya çapında eğitimle ilgili olan haber ve yenilikleri takip etmelidir. Bu davranışları gerçekleştirmesi ve kendi yaptıklarını da duyurması için sosyal medya çokça önem arz etmektedir.” ( $\mathrm{K}_{2}$, Kadın, Okul Öncesi Öğretmenliği)

"Internet ve dolayısıyla sosyal medya sayesinde hiçbir alanda sinırlar kalmadi. İyi uygulamaların yaygınlaşması, teknolojinin entegrasyonu ve bu ikisinin sadece aynı okuldaki meslektaşınız ile değil yurtdışındaki meslektaşlarınızla uygulanması, çıtıların kontrol edilmesi söz konusu. Ayrıca yine Erasmus gibi projelerle ortak yapılan uygulamalar ve ülke ziyaretleri ile alınan eğitimlerle gelişme söz konusudur.” (K 10, Kadın, Fizik Öğretmenliği)

\section{Ĕ̈itim Programı Liderliği Etkinliği Sonrasında Katılımcılardan Elde Edilen Bulgular}

Program liderliği etkinliği sonrası katılımcılardan elde edilen verilerin ayrıntılı incelenmesi sonucunda program liderliğinin dört ana tema etrafında şekillendiği belirlenmiştir. Bu temalar (1) Currere Yöntemi, (2) Sosyal Sorumluluk, (3) Çağın Sunduğu Firsatlar, (4) Tasarımla Anlamlandırma olarak adlandırılmıştır. Tablo 4'te ana temalar ve bu temalara ait kategoriler sunulmuştur. Kategorilere ait kodlar ise her temanın ayrı ayrı incelendiği başlıklarda sunulmuştur.

Tablo 4. Program Liderliğine İlişkin Temalar ve Kategoriler

\begin{tabular}{ll}
\hline Temalar & Kategoriler \\
\hline & Anlamlandırma Yolculuğu \\
Currere Yöntemi & Otobiyografiye Yoğunlaşma \\
& İşbirliği \\
& Girişimcilik \\
& Olumlu Okul İklimi/Ortamı \\
& Paydaşlar \\
Sosyal Sorumluluk & Sorunlar \\
& Toplum \\
& \\
& Dünyayı Tanıma \\
& Güncellik \\
& Dijital Araçlar
\end{tabular}


Tasarıma Dayalı Anlamlandirma

Anlamlandırmayı Sağlama

Sonu Düşünerek Başlama

Performans Görevlerini Netleştirme

Tablo 4’te program liderliğine ilişkin dört tema ve on dört farklı kategori görülmektedir. Birinci tema olan currere yöntemi; bireysel anlam arayış sürecini, ikinci tema olan sosyal sorumluluk; eğitimcinin içinde bulunduğu topluma katk1 sunabileceği etkileşim sürecini, üçüncü tema olan çağın sunduğu firsatlar; yaşanılan dönemin imkânlarından faydalanma ve yeniliklere açık olmayı, dördüncü tema olan tasarıma dayalı anlamlandırma; öğrenme ortamlarını anlam merkezli olarak daha etkili hale getirme çabalarını temele almıştır.

\section{Currere yöntemi}

$\mathrm{Bu}$ tema altında toplanan kategoriler anlamlandırma yolculuğu ve otobiyografiye yoğunlaşma olarak isimlendirilmiştir. Şekil 2'de bu temaya ilişkin kategoriler ve kodlar sunulmuştur.

Şekil 2. Currere Yöntemi Temasına Ait Kategoriler ve Kodlar

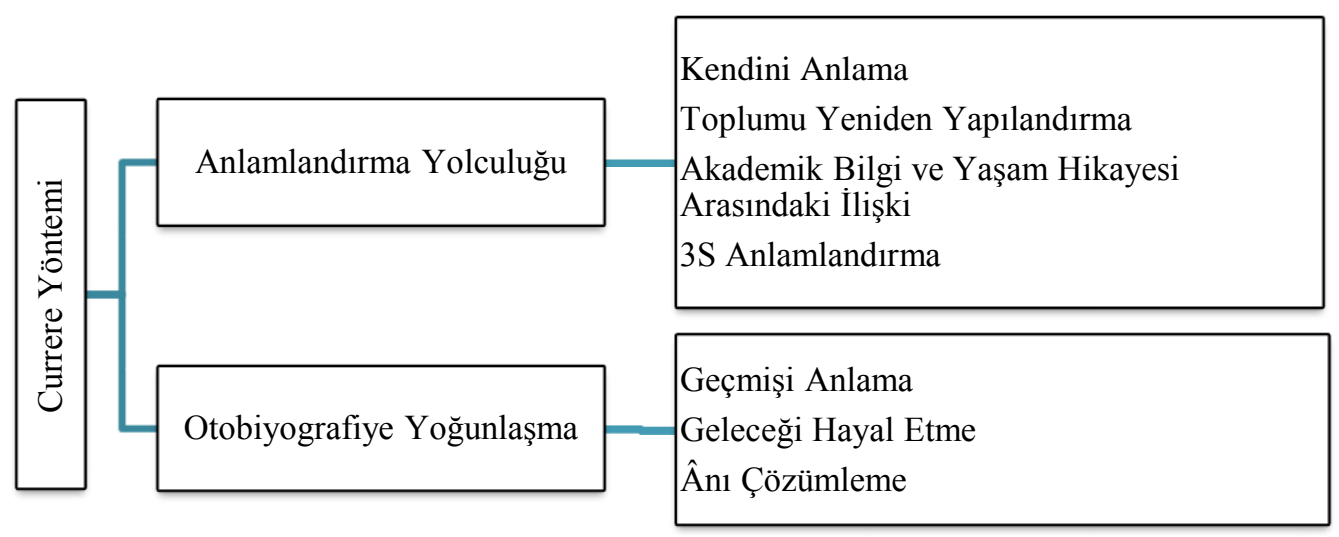

Şekil 2'de görüldügü gibi currere yöntemi teması altında bireyin kendi anlamlandırma sürecine yoğunlaşmasıyla akademik bilgisi ve kendi hayat öyküsü arasındaki ilişkiyi fark etmesi incelenmiştir. Öğretmenlerin kendi gelişim ve değişim yolculuklarının farkında olmaları ve bu farkındalıklarını eğitim sürecinde dikkate alma durumları yorumlanmıştır.

Öğretmenler tarafından currere yönteminin bireysel anlama yolcuğunu temele aldığı sıklıkla vurgulanmış ve öğretmenin kendi yaşam deneyimlerinden öğrencilerin kişisel öğrenme sürecine uzanan bir köprü görevi gördüğ̈̈ ifade edilmiştir. Kendi tecrübelerini değerlendirerek yorumlayan öğretmenlerin buradan edindiği aydınlanmalarla öğrenme-öğretme sürecine daha 
çok katkı sunacağı, sonraki planlamalarında buradan edindiği tecrübeleri dikkate alacağı vurgulanmış ve hedeflerin gerçekleştirilmesinde bu konunun önemine dikkat çekilmiştir. Öğretmenlere ait ifadelerden bazıları şöyledir:

"Currere yöntemi öğretimi üstlenen kişinin anlama yolculuğuna odaklanmaktadır. $\mathrm{Bu}$ anlama yolculuğunda elde edilen çıkarımlar ise ögretmenin kendi anlama yolculuğundan yola çıkarak ögrencilere kadar uzanan bir köprü görevi görmektedir. Yaşanan deneyimler ise öğrencinin anlamlandırma sürecinde farkındalık kazanmaya yardımcı olur.” (K4, Kadın, Fen Bilgisi Öğretmenliği).

"Bireylere geçmişlerini hatırlama ve geleceklerini hayal etme firsatı sunarak onlara deneyimleri hakkında daha geniş ve derin bir anlayış sağlamanın yanı sıra bireyin kendi anlamlandırma sürecine yoğunlaşması akademik bilgi ile kendi hayat öyküsü arasındaki ilişkiyi fark etmesine katkı sağlamaktadır.” (K9, Kadın, Beden Eğitimi Öğretmenliği)

"Currere, ĕgitimcileri ve ögrencileri kendilerinin otobiyografik incelemesini yapmaya teşvik ettiği için mutlaka katkı sağlar. Bu yöntemin temel ilkesi olan öznellik kişinin kendi yolunu, arayışını, öğrenme macerasını şekillendirecektir." ( $\mathrm{K}_{1}$, Erkek, Sınıf Öğretmenliği)

Sosyal sorumluluk

$\mathrm{Bu}$ tema altında toplanan kategoriler işbirliği, girişimcilik, olumlu okul iklimi/ortamı, paydaşlar, sorunlar ve toplum olarak isimlendirilmiştir. Şekil 3 'te kategoriler ve bu kategorilere ait kodlar sunulmuştur. 
Şekil 3. Sosyal Sorumluluk Temasına Ait Kategoriler ve Kodlar

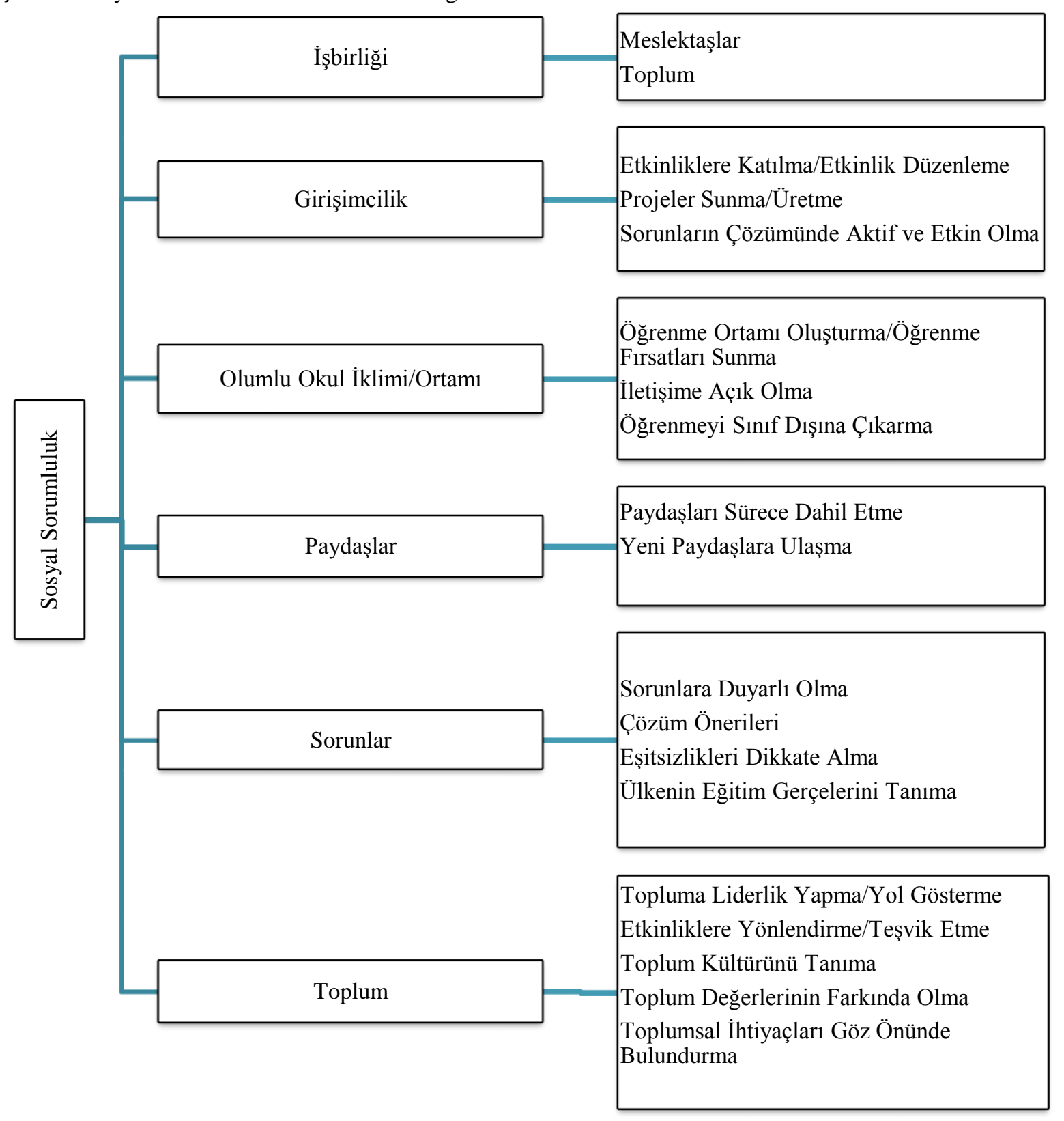

Şekil 3'te görüldüğü gibi sosyal sorumluluk teması altı kategoride incelenmiştir. Kategoriler ve bu kategoriler kapsamındaki kodlar öğretmenlerin eğitim sürecinde sıklıkla karşılaştıkları ve çözüm odaklı çalıştıkları durumlar üzerinden yorumlanmıştır. Bu tema öğretmenlerin sadece öğretim yapma anlayışından çıkarak en yakın çevreden başlayarak hayatla iç içe geçmiş bir eğitim ortamı oluşturmaları düşüncesine odaklanmaktadır. Yapılan uygulamalar ve elde edilen kazanımların toplumun farklı kesimlerine yansıtılması ve sorunların çözümünde kullanılması öğretmenlerin en çok vurguladıkları durumların başındadır. Okul ikliminin sağlıklı bir şekilde oluşturulması, süreç içinde geniş katılımcı bir anlayışın benimsenmesi, toplumun farklı kesimlerinin de eğitimle ilgili kararlarda görev ve sorumluluk almasını vurgulayan ifadeler kullanmışlardır. Bu ifadelerden bazıları şu şekildedir:

"Çevresindekileri problemleri çözmeye, yeni bilgilere adapte olmaya yönlendirmek, toplum yararına bir hareket ortaya koymak adına sürekli yeni şeyler 


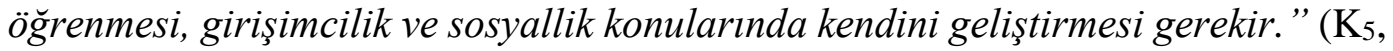
Kadın, İngilizce Öğretmenliği)

"Eğitim programı lideri, sadece eğitim programıla değil güncelle, toplumla, uluslararası olan her şeyle, ögrencinin akademik değil duygusal ve fiziksel ihtiyaçlarıyla da ilgilenen, çocuğa ve topluma dokunan herkesle iş birliği kurabilen kişidir.” ( $\mathrm{K}_{2}$, Kadın, Okul Öncesi Öğretmenliği)

"Eğitim program liderliği, uygulamada temel aldı̆̆ı öğretim programından yola çıkarak başta ögrenciler olmak üzere olumlu etki yaratabilme, bunun için gerekli şartları oluşturabilme ve programı işlevsel hale getirebilmedir." ( $\mathrm{K}_{4}$, Kadın, Fen Bilgisi Öğretmenliği)

Program liderliği konusunda üzerinde en çok durulan konulardan biri yapılan uygulamaların topluma katkı sunması, toplumu geliştirmesi ve karşılaşılabilecek sorunların çözümüne yardımcı olmasıdır. Bu bağlamda bireylerin potansiyellerinin ortaya çıkarılması konusunda kendilerine destek olunması, ihtiyaçların tespit edilerek giderilmesinin planlanması ve sosyal sorunlara yönelik farkındalığın oluşması/oluşturulması katılımcıların önemsedikleri durumlardandır. Bazı katılımcı ifadeleri şu şekildedir:

"Dahil olduğumuz ĕgitim ortamının çevresel, yönetsel ve ögrenci yönünden ihtiyaçlarına göre programı bireyselleştirme yönünde adımlar atan, sorumluluk alan, önder kişilerdir. ”( $\mathrm{K}_{10}$, Kadın, Fizik Öğretmenliği)

"Öğretmenlerin ve eğitimcilerin ilk başta çevrelerinde gelişen olaylara farklı bir bakış açısı ve gözle bakmaları gerekir. Farkındalıklarının yüksek olması gerekir. Toplumdaki sosyal sorunlara duyarlı olmalarl gerekir. Yeniliğe açık olup, risk almaları gerekir. Toplumu ilgilendiren sorunların çözümünde gönüllü olmaları ve sorumluluk almaları gerekir. Çünkü eğitim dediğimiz, okul dediğimiz şey bir bakımdan eğitim programlarıdır.” ( $\mathrm{K}_{15}$, Erkek, Sosyal Bilgiler Öğretmenliği)

“Özüne yönelik bir kavrayış sağlar, seçimler tercihler akademik rotada kendini fark etmeyi sağlar her şeyden önce ögretmenin ögretmeye yönelik tutumunda olumlu ve olumsuz yönlerini değerlendirmesi için ışı tutar, yürüdügün yolda karanlıkları görünür kılan bir meşaledir”. (K${ }_{11}$, Kadın, Rehberlik ve Psikolojik Danışma)

\begin{abstract}
"Ĕ̈itim programı lideri, lider olan öğretmenin özelliklerinden biri kendi forma görevlerinin dişında isteyerek farklı sorumluluklar alan bireylerdir. Toplumun herhangi bir alanında gördüğü bir soruna yönelik toplumsal duyarlılık duygusu ile çözüm yolları üretir. Sosyal sorumluluk alabilen gönüllü çalışmalar yapan ögretmen aynı zamanda lider ögretmendir. Bu çalışmalarda kendine yapabileceklerine yönelik firsatlar oluşturabilir. Bunlar ile ilgili projeler gelişstirebilir. Öğretmenlerin üniversitede aldıkları dersler ve yaptıkları çalışmalar meslekleri ile ilgili bu faaliyetleri destekler niteliktedir". ( $\mathrm{K}_{7}, \mathrm{Kad} ı$, Rehberlik ve Psikolojik Danışma)
\end{abstract}

Çă̆ın sunduğu firsatlar 
$\mathrm{Bu}$ tema altında toplanan kategoriler dünyayı tanıma, güncellik ve dijital araçlar şeklinde isimlendirilmiştir. Şekil 4'te kategoriler ve bu kategorilere ait kodlar sunulmuştur.

Şekil 4. Çağın Sunduğu Fırsatlar Temasına Ait Kategoriler ve Kodlar

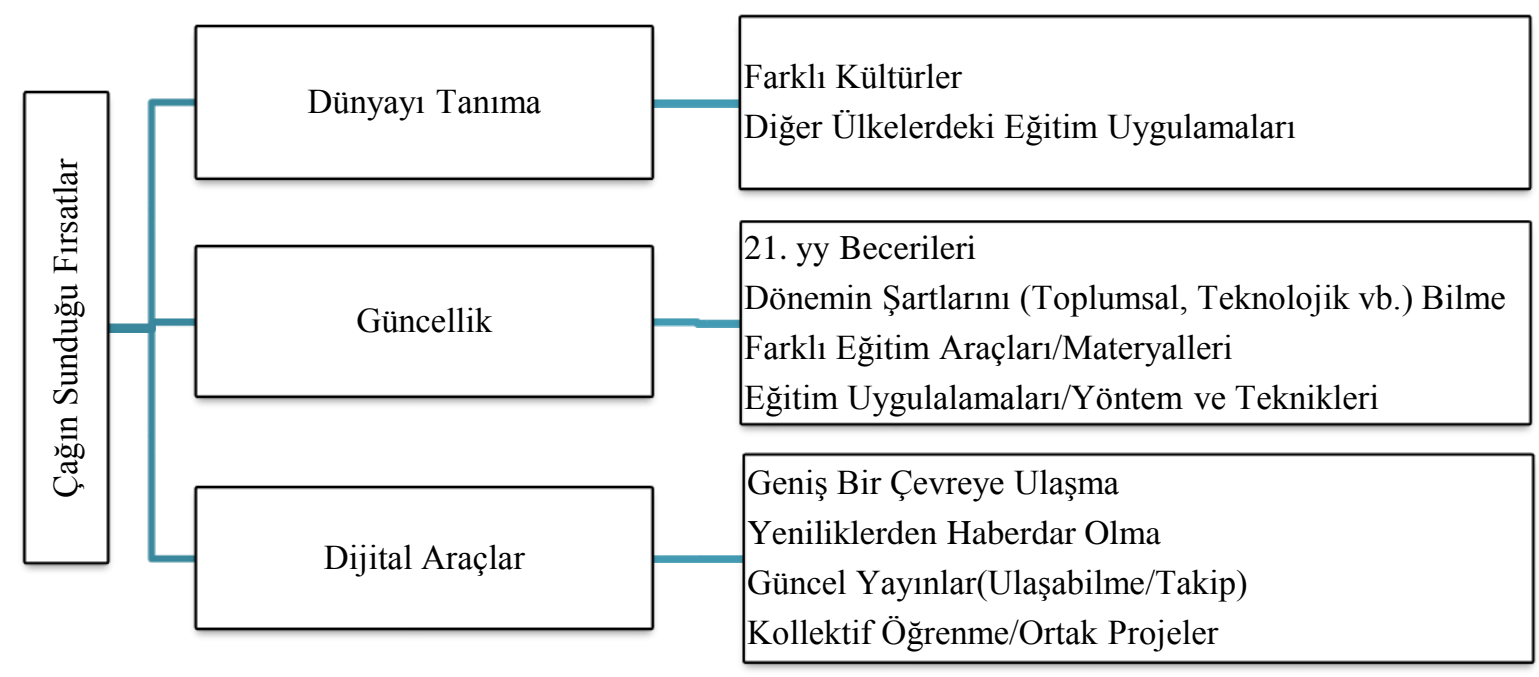

Şekil 4'te görüldüğü gibi çağın sunduğu firsatlar teması üç kategori altında incelenmiştir. Kategoriler ve kodlar eğitim sürecini daha etkili hale getirebilecek, farklı bölgesel ve küresel uygulamaların göz önüne alındığı, her dönemin kendi şartları içerisinde farklı firsatlar sunan araçların kullanılması üzerinden yorumlanmıştır.

Öğretmenler bir program liderini anlatırken özellikle dönemin yeniliklerinden haberdar olmayı, güncel dijital araçlar hakkında farkındalığın olması gerektiğini ve imkânlar ölçüsünde bu farkındalığı öğrenme ortamına taşımanın önemini vurgulamışlardır. Bunun yanında dünyanın farklı bölgelerinden eğitim uygulamalarının da mutlaka takip edilmesi ve bu tecrübelerden faydalanılmasını önemsediklerini belirtmişlerdir. Bazı ifadeler şu şekildedir:

"Ĕgitim programı liderliği ĕgitim programlarını değişen koşullara, değişen bilgiye, ögrenen ilgi ve ihtiyaçlarına göre uyarlamanın yanında tüm paydaşlarla işbirliği içerisinde çalışma, 21. yüzyll becerileri, sosyal sorumluluklar ve değerleri göz önünde bulundurarak ögretim sürecini olabilecek "en iyi" hale getirme çabası olarak tanımlanabilir". (K $\mathrm{K}_{16}$, Kadın, İngilizce Öğretmenliği)

"Yeniliklerden haberdar, projelere katılıma istekli, girişimci, iyi bir dinleyici, iletişimi yüksek ve sorumluluk alabilen planlı kişilerdir”. ( $\mathrm{K}_{8}$, Kadın, Matematik Öğretmenliği)

"Risk alabilen, değişimin takipçisi ve uygulayıcısl, dijital dönüşüme hâkim, hayat boyu ögrenen, program tasarımı ve uyarlanmasına ilişkin gerekli yeterliliklere sahip, toplumsal duyarlılı̆̆ olan, kendini geliştiren”. ( $\mathrm{K}_{16}$, Kadın, İngilizce Öğretmenliği)

Güncel kalmanın önemine değinen katılımcılar bu konuda önemli etkiye sahip geniş bir bağlantı ağ1 kurmayı vurgulamışlardır. Bu bağlantılar hem öğretmenlerin güncel kalmasına katk1 sunacak hem de yenilikleri başkalarıyla paylaşarak bilginin ve tecrübenin yayılmasına imkân 
tanıyacaktır. Ortaya çıkacak ortak çalışmaların ürünleri firsatların daha çok kişi tarafından paylaşılmasını sağlar. Bu konudaki bazı ifadeler şu şekildedir:

"Uluslararasılaşma ve sosyal medya (dijital dünya) eğitim programı liderine oldukça fazla firsatlar sunmaktadır. Bu firsatların çoğu da bilgilerin paylaşılması için olanak sağlamasıdır. Bilgiye ulaşmak için kolaylık sunmasıdır”. ( $\mathrm{K}_{1}$, Erkek, Sinıf Öğretmenliği)

"Dünya eğitim sistemlerini yerinde görmeyi ve karşılaştırma imkânını sunmaktadır. Vermiş olduğu çok yönlü bakış açısı ile liderlik özelliklerinin gelişmesini sağlamaktadır” . ( $\mathrm{K}_{6}$, Erkek, Bilgisayar Öğretmenliği)

"Farklı kültürleri, coğrafyaları, insanları tanıma imkânı veriyor. Aynı zamanda kurulan iletişimlerle birçok kişiye ulaşmayı sağlıyor”. (K $\mathrm{K}_{13}$, Erkek, Aile Ekonomisi ve Beslenme Eğitimi)

"Ĕ̆itim programı lideri, değişimin en önemli temsilcisi olarak (change agents) uluslararası gelişmeleri yakından izleyebilmeli, özellikle eğitim alanındaki güncel meseleleri takip edebilmelidir. Bu amaçla, farklı ülkelerde eğitim alabilir, araştırmacı olarak kurumlarda yer alabilir, değişim programlarına katılabilir. Sosyal medya ile de eğitim programı liderleri uluslararasılaşmanın ve pandemiyle birlikte daha da dijitalleşen dünyanın takipçisi olabilir, teknolojiyi ve medyayı ögretim süreçlerinde kullanabilir hale gelebilir”. ( $\mathrm{K}_{16}$, Kadın, İngilizce Öğretmenliği)

\section{Tasarıma dayalı anlamlandırma}

$\mathrm{Bu}$ tema altında toplanan kategoriler anlamlandırmayı sağlama, sonu düşünerek başlama ve performans görevlerini netleştirme şeklinde isimlendirilmiştir. Şekil 5'te kategoriler ve bu kategorilere ait kodlar sunulmuştur.

Şekil 5. Tasarıma Dayalı Anlamlandırma Temasına Ait Kategoriler ve Kodlar

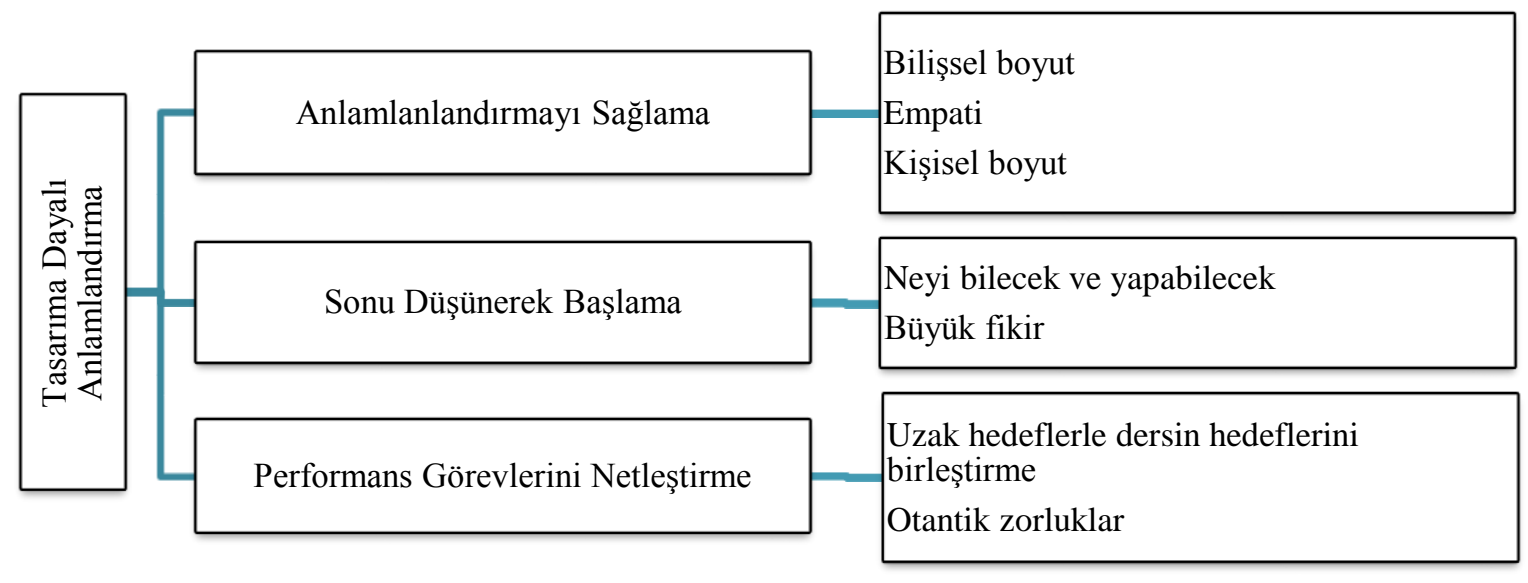

Şekil 5'te görüldüğü gibi tasarıma dayalı anlamlandırma üç kategori altında incelenmiştir. Bu kategoriler, öğrenme sürecinin doğru, etkili planlanması ve uygulamalara yön verip derinlik katacak bakış açıları doğrultusunda yorumlanmıştır. 
Öğrenme sürecine vurgu yapan katılımcılar kişisel anlamlandırma sürecinin önemine dikkat çekmiş ve "yolculuk" olarak ifade ettikleri bu sürecin tasarlanmasında, planlanmasında bireyin kişisel özelliklerinin dikkate alınmasını vurgulamışlardır. Bu konuda bireyi kendi konfor alanından çıkartacak ve bilişsel süreçlerini harekete geçirecek tasarımlardan bahseden katılımcılara ait bazı ifadeler şu şekildedir:

"Eğitim programı liderliği: Bireyin kendini anlama ve öğrenme yolculuğu için kendi konforundan ödün vererek risk almasl; yeni yerler, yeni insanlar farklı kültürler tanıma isteğidir”. (K $\mathrm{K}_{10}$, Erkek, Aile Ekonomisi ve Beslenme Eğitimi)

"En temel bileşeni önemli olan ne?" sorusunu sorması ve ona yoğunlaşmasıdır. Insan aklına meydan okuyan problemlere çözüm araması ve yoğunlaşmasıdır. Insanlarl sosyal yönü ile etkilemeye ă̆ırlık vermesidir. Ĕ̈itim programı liderinin öncelikle sosyal yönünün kuvvetli olmasi gerekir. Değişime, dönüşüme ve yeni fikirlere açık olması gerekir. Topluma farklı bir gözle bakarak merkeze toplumu ve bireyi alması gerekir. Sosyal sorunlara karşı duyarlılı̆̆l olmasl gerekir. Büyük fikrin ne olduğunu belirlemesi gerekir”. (K $\mathrm{K}_{15}$, Erkek, Sosyal Bilgiler Öğretmenliği)

$\mathrm{Bu}$ tasarım süreci boyunca dikkati üzerine çekecek, öğrenme ortamına farklı bir bakış açısı kazandıracak bir bakıma güdülenmeyi artıracak kavramlar üzerine değerlendirmeler yapan katılımcılar, kısaca "büyük fikir" olarak ifade ettikleri anlayışı sıklıkla vurgulamışlardır. Bu konu hakkında bazı ifadeler şu şekildedir:

"Eğitim programı liderliğinin belki de ne önemli kavramı önemli olana odaklanması yani büyük fikire öncelik vermesidir. Ë̆itimin içine bireyi, toplumu, doğayl, çevreyi katan bir bakış açısıdır." ( $\mathrm{K}_{15}$, Erkek, Sosyal Bilgiler Öğretmenliği)

"Dersin asıl amacl olan büyük fikir üzerine düşünen ve bunu kendi öğrenme ve anlama yolculuklarlyla geliştiren ögrenci ve ögretmenl er derin anlama ulaşabileceklerdir. Bu da kalıcı bilgilere ulaşma ihtimallerini arttıracaktır". (K5, Kadın, İngilizce Öğretmenliği)

\section{TARTIŞMA VE SONUÇ}

Katılımcıların eğitim programı liderliği yeterliliklerinin geliştirilmesi amacıyla yapılan bu araştırmada, kuramsal yapıdan hareketle belirlenen alt boyutlar doğrultusunda katılımcıların çalışma öncesi ve sonrası program liderliği kavramıyla ilgili bakış açıları ve değerlendirmeleri yorumlanmıştır. Araştırmanın başlangıcında katılımcıların ifade ettikleri görüşlerinin analizi sonucunda iki boyutlu bir yapı ortaya çıkmıştır. Bu boyutlar toplumsal duyarlılık ve sosyal sorumluluk yeterliliği ve çağın sunduğu firsatlara yönelik farkındalık ve yararlanma yeterliliği olarak adlandırılmıştır. Program liderliği ile ilgili hazırlanan eğitim etkinliği ve faaliyetlerinin uygulanmasının ardından katılımcıların ifade ettikleri görüşlerin analizi sonucunda ise dört boyutlu bir yapı ortaya çıkmıştır. Bu boyutlar; currere yöntemi, sosyal sorumluluk, çağın sunduğu firsatlar ve tasarıma dayalı anlamlandırma olarak adlandırılmıştır. Eğitim öncesi ve sonrasında elde edilen sonuçlara göre ortak iki boyut dışında Currere yöntemi ve tasarıma dayalı anlamlandırma olmak üzere farklı iki boyutun daha ortaya çıktığı görülmektedir. Ayrıca yapılan uygulamalar kapsamında program liderliği kavramını kendi düşünce ve deneyimlerine göre yorumlamaları istenen katılımcıların çalışma öncesinde öğretmenlere ait özellikler olarak 
kabul edilebilecek genel ifadeler (değer veren, saygılı, alan bilgisi yeterli vb.) kullandıkları görülmüştür. Çalışma sonrasında yapılan değerlendirmelerinde ise program liderliği ile ilgili anahtar kavramları (Sosyal sorumluluk, gönüllülük, eğitsel otobiyografi, anlamlandırma vb.) sıklıkla kullandıkları görülmüştür.

Bir öğretmenin alan bilgisi, öğretim ve yönetim becerisi, öğrencilerini tanıması, öğretmenliğe adanmışlı̆̆ 1 , kendini geliştirme isteği, meslektaşlarıyla işbirliği ve yeni fikirlere açıklığı programın başarısında önemli role sahiptir (Posner, 1995). Ulaşılan sonuçlar doğrultusunda değerlendirildiğinde program liderliğine ait boyutların Posner'ın vurguladığ 1 başlıkları karşıladığı düşünülmektedir. Currere yöntemi ile kendisini daha iyi tanıyan öğretmen, çevresini anlamlandırırken daha geniş bir perspektiften düşünebilecektir. Varsa eksik yönlerini fark edecek, bunun için telafi yolları arayacak, gelişimini sürekli kılacaktır. Bu gelişim sürecinin yansımasının okul yaşamında da kendini göstereceği düşünülmektedir.

Eğitim programı kuramcısı Schwab (Akt. Henderson, Castner ve Schneider, 2018) eğitim programları alanının uygulamalı bir alan olduğu için, eklektik sanatların dinamik program konularının ayrılamaz bir parçası olduğu görüşündedir. Ona göre sosyal ve davranışsal bilimlerin birbiriyle zıtlaşan tavsiyelerini alabilmek için hepsi ortaya getirilip eklektik olarak birleştirilmelidir. Çalışmada bu görüşü destekler bulgulara ulaşılmıştır. Uzak hedeflerle dersin hedeflerini birleştirme, farklı ülkelerdeki eğitim uygulamalarından haberdar olma, toplumun değerlerinin ve ihtiyaçlarının farkında olma ve akademik bilgi ile yaşam hikayesini birleştirme gibi alanlardaki bilgi ve beceriler eğitim programı liderliği yeterlikleri olarak ortaya çıkmıştır. Pinar (2004) öğretmenlerin kendi currere anlamlandırma ve öğrenme yolculuklarının lideri olduklarında, aynı zamanda eğitim programlarının kuramcısı olmaya başlayacaklarını ifade etmektedir. Öğrencilerin kişisel öğrenme ve anlamlandırma yolculuklarını kolaylaştırmayı seçen eğitimcilerin benzer bir anlayış yolculuğu yapmadan bunu başaramayacakları düşünülmektedir. Son yıllarda literatürde currere yöntemine vurgu yapıldığ1 görülmektedir. Gerçek profesyonel sorumluluğun, öğretmenin yeterliliklerini özenli bir şekilde öğrencilere ve topluma yönlendirmesi olduğu ifade edilmektedir (Noddings, 2013). Eğitimcilerin sosyal sorumluluk duygusu ile problem çözme sürecinde meşgul olmaları istenen bir durumdur. Program liderliği öğretmenlerin, değişimin sadece pasif alıcıları olmalarının ötesinde, değişim sürecinde etkin olarak yönetme yönlerini güçlendirir (Harris ve diğerleri, 2020) ve kendi öğretim planları üzerinde bağımsızlıklarını sağlayarak öğretmenlerin sorumluluklarını artırır. Sınıf içinde ve dışında öğrenme firsatları oluşturma, bakım ve ilgi için yollar geliştirme, imkânları artırma için paydaşları harekete geçirme program liderinin görevleri olarak görülmektedir (Akbaş ve Keskin, 2021). Barth (2001)'ın belirttiği gibi eğitim ortamlarında kendilerini sınırlayan veya engelleyen olumsuzluklara karşı bir bakıma başkaldırı olarak yorumlanan liderlik yeterliliklerinin geliştirilmesi, eğitim sorunlarına çözümde bir çıkış noktası olabilir.

\section{KAYNAKÇA}

Akbaş, O. \& Keskin, A. (2021). Eğitim programı liderliği. İçinde G. Ekici \& S. M. Özdemir (Ed.), Çağdaş bakış açısıyla eğitimde program geliştirme ve değerlendirme(301-328). Ankara: Nobel Yayınevi.

Akbaş, O., Taş, İ. D., Duman, S. N. \& Keskin, A. (2018). Osmanlı dönemi eğitim felsefesi. İçinde M. Ergün \& A. Çoban (Ed.), Eğitim felsefesi (205-234). Ankara: Pegem Akademi Yayınları.

Barth, R. S. (2001). Learning by heart. San Francisco: Jossey Bass.

Bolman, L. G. \& Deal, T. E. (2017). Reframing organizations: artistry, choice and leadership (6 bs.). San Francisco: Jossey Bass. 
Büyüköztürk, Ş., Kılıç Çakmak, E., Akgün, Ö. E., Karadeniz, Ş. \& Demirel, F. (2012). Bilimsel araştırma yöntemleri (13.Bask1.). Ankara: Pegem Akademi Yayınları.

Christensen, L. B., Burke Johnson, R. \& Turner, L. A. (2015). Araştırma yöntemleri desen ve analiz. (A. Aypay, Çev. Ed.). Ankara: Anı Yayıncılık.

Creswell, J. W. (2017). Eğitim araştırmaları nicel ve nitel araştırmanın planlanması, yürütülmesi ve değerlendirilmesi (H. Ekşi, Çev. Ed.). İstanbul: EDAM.

Demeuse, M. \& Christine, S. (2016). Politik kararlardan uygulamaya ĕgitimde program geliştirme (Y. Budak, Çev.). Ankara: Pegem Yayınevi.

Dewey, J. (2013). Deneyim ve eğitim (S. Akı1lı, Çev. 3 bs.). Ankara: ODTÜ Yayıncılık.

Doğan-Yenisey, K. (2020). Gönüllülük ve hukuki çerçevesi. İçinde E. Erdoğan, P. Uyan-Semerci, N. Yentürk \& L. Yurttagüler (Ed.), Türkiye'de gönüllü̈lük deneyimler, sinırlllıklar ve yeni açılımlar (179-206): İstanbul Bilgi Üniversitesi Yayınları.

Ellis, A. K. (2015). Eğitim programı modelleri (A. Arı Ed.). Konya: Eğitim Yayınevi.

Ertürk, S. (2013). Eğitimde program geliş̧tirme (6 bs.). Ankara: Edge Akademi.

Freire, P. (2019). Kültür işçileri olarak ögretmenler (Ç. Sümer, Çev.). İstanbul: Yordam Kitap.

Gladwell, M. (2019). Çizginin dışındakiler (A. Özer, Çev.). İstanbul: MediaCat

Harris, A., Jones, M. \& Crick, T. (2020). Curriculum leadership: a critical contributor to school and system improvement. School Leadership and Management, 40(1), 1-4. doi:10.1080/13632434.2020.1704470

Hawthorne, R. \& Henderson, J. (2000). Transformative curriculum leadership. NJ: Merrill-Prentice Hall.

Henderson, J. (2014). Reconceptualizing curriculum development: inspiring and informing action. Routledge.

Henderson, J. (1998). Transformative curriculum leadership. Teaching Education, 9(2), 69-70. doi:10.1080/10476210.1998.10335497

Henderson, J. G. (2010). Curriculum leadership. İçinde C. Kridel (Ed.), Encyclopedia of curriculum studies (Vol. 1, pp. 220-223). Thousand Oaks, California: Sage Publications.

Henderson, J. G., Castner, D. J. \& Schneider, J. L. (2018). Democratic curriculum leadership: critical awareness to pragmatic artistry. Rowman \& Littlefield.

Hilav, S. (2019). Felsefe el kitabı (8 bs.). İstanbul: Yapı Kredi Yayınları.

Hsieh, C.-C., Tseng, H.-K. \& Chen, R. J.-C. (2021). Transformation from traditional schools to alternative schools: curriculum leadership of the principals of Taiwanese aborigines. Asia Pacific Education Review, 22(1), 53-66. doi:10.1007/s12564-020-09663-9

İhsanoğlu, E. (2000). Başhoca İshak Efendi. İçinde Türkiye Diyanet Vakfi İslam Ansiklopedisi (clt. 22, ss. 529-530). Ankara: Türkiye Diyanet Vakfi.

Kumar, R. (2015). Araştırma yöntemleri yeni başlayanlar için adım adım araştırma rehberi (Ö. Çokluk, Ed.; Ö. Çokluk, G. Şekercioğlu, H. Atak, Çev.), Ankara: Edge Akademi.

Kumar, R. (2011). Research methodology: a step-by-step guide for beginners (3. bs.).Sage Publications.

Mackenzie, G. N. (1949). Curriculum leadership. Educational leadership, 6(5), 264-271.

Marsh, C. J. \& Willis, G. (2007). Curriculum: alternative approaches, ongoing issues (4 bs.). New Jersey: Pearson Merrill Prentice Hall.

MEB. (2020). Millî Eğitim istatistikleri örgün eğitim 2019-2020. Erişim adresi http://sgb.meb.gov.tr/www/icerik_goruntule.php?KNO=396

Miles, M. B. \& Huberman, A. M. (2015). Nitel veri analizi (S. Akbaba Altun \& A. Ersoy, Çev. Ed.). Ankara: Pegem Yayıncilık.

Noddings, N. (2013). Caring: a relational approach to ethics and moral education. University of California Press.

Patton, M. Q. (2014). Nitel araştırma ve değerlendirme yöntemleri. (M. Bütün \& S. Beşir Demir, Çev. Ed.). Ankara: Pegem Yayıncilik.

Posner, G. J. (1995). Analyzing the curriculum. New York: Mc-Graw-Hill Humanities Social.

Pinar, W. F. (1994). The method of" Currere"(1975). Counterpoints, 2, 19-27.

Pinar, W. F. (2004). What is curriculum theory? Routledge.

TDK. (2020). Genel Türkçe Sözlük. Erişim adresi https://sozluk.gov.tr/ 
Tomlinson, C. A., Kaplan, S. N., Renzulli, J. S., Purcell, J. H., Leppien, J. H., Burns, D. E., . . Imbeau, M. B. (2017). Koşut eğitim programı (M. A. Sözer \& S. Emir, Çev.). Ankara: Pegem Akademi.

Tyler, R. W. (2014). Ĕgitim programlarının ve ögretimin temel ilkeleri. Ankara: Pegem Akademi. Varış, F. (1996). Eğitimde program geliştirme teori ve teknikler: Ankara Universitesi Basımevi. Wiggins, G., Wiggins, G. P. \& McTighe, J. (2005). Understanding by design: ASCD.

Wynn, C. M., Wiggins, A. W. \& Berger, D. (1997). The five biggest ideas in science. Journal of Chemical Education, 74(6), 627.

Yurttagüler, L. (2020). Gençlik, gönüllülük ve katılım. İçinde E. Erdoğan, P. Uyan-Semerci, N. Yentürk \& L. Yurttagüler (Ed.), Türkiye'de gönüllülük deneyimler, sinırlılıklar ve yeni açılımlar: İstanbul Bilgi Üniversitesi Yayınları.

Yurtseven, N. (2016). Yabancı dil öğretiminde eylem araştırmasına dayalı UBD (anlamaya dayalı tasarım) uygulamalarının öğretmenler ve öğrenciler üzerindeki yansımalarının incelenmesi (Doktora tezi). Yıldız Teknik Üniversitesi Sosyal Bilimler Enstitüsü, Ankara.

\section{EXTENDED ABSTRACT}

\section{Introduction}

The concept of curriculum leadership, which brings together the qualities of curriculum, leadership, and teaching concepts in a meaningful way, has become an educational topic that is frequently studied in the literature to determine what knowledge, skills, and competencies educators should have as a leader. It has become essential to determine the basic dimensions of curriculum leadership, which plays a role in solving social problems affecting the classroom. A learning leader does not only see meaning as a subject but also evaluates it individually and socially. In this research conducted in this direction, a 55-hour scientific activity program on curriculum leadership was planned and implemented within the scope of the TUBITAK 2237A project.

\section{Method}

The before-and-after study design was used as the research design. A scientific education activity was presented to the participants in the scope of this research design. It was aimed to compare the changes and developments they experienced before and after the educational activity. Participants in the study were determined by purposeful sampling model. Twenty participants, consisting of teachers, education administrators, faculty members, and graduate students from different universities and programs, took part in the research. Interview forms and diaries developed by the researchers were used to get the participants' before- and after-situation views and evaluations. The data obtained were analyzed and compared as before and after the situation. In the research in which descriptive analysis was used, the findings were presented in themes, categories, and codes and supported with quotations.

\section{Findings}

The findings of the study are presented in two ways as before the situation and after the situation. Two themes were determined with the findings obtained before the situation. These themes are; social sensitivity and social responsibility competence, awareness of the opportunities offered by the age, and the competence to benefit. The categories of cooperation, entrepreneurship, positive school climate, problems, and society were reached in social 
sensitivity and social responsibility competence. The categories of knowing the world, up-todateness, and digital tools were emerged in the theme of awareness of the opportunities offered by the age and competence to benefit. The themes that emerged from the findings obtained after the training, currere method, social responsibility, opportunities of the age, and understanding by design were determined. Under the theme of the currere method, the categories of journey of meaning and concentration on autobiography were created. In the theme of social responsibility, cooperation, entrepreneurship, positive school climate/environment, stakeholders, problems, and society categories were reached. In the theme of the opportunities of the age; the categories of knowing the world, up-to-dateness and digital tools were determined. Finally, in the design-based interpretation theme, categories were obtained under the headings of providing meaning, starting by thinking about the end, and clarifying performance tasks.

\section{Conclusion}

Before the scientific training event and application studies, social sensitivity and social responsibility competencies for the curriculum leadership had come to the fore. After the training event, it was determined that the theme of social responsibility was expressed more frequently in different categories. In addition to the categories of cooperation, entrepreneurship, positive school climate, problem, and society that emerged under this theme, it was determined that the stakeholder category was also encountered after the training. From this point of view, it can be said that the idea of "stakeholder" comes to the fore in the curriculum leadership. On the other hand, a similar theme emerged after the training compared to the theme about the opportunities offered by the age before the study. It showed no significant change in the participants' views after the scientific training activity on this theme. In addition to these, two new themes were emerged after the training were determined. Currere method and design-based interpretation themes emerged based on the newly acquired knowledge and competences of the participants after the training event. No opinions on these themes were found by the participants before the training. These themes emerged after the training. This situation can be interpreted as the trainings given to the participants gain new knowledge, skills and competencies.

\section{Kaynak Gösterimi İçin (For cited in):}

Akbaş, O., Duman, S.N. \& Keskin, A. (2021). Eğitim programi liderliği yeterlilikleri üzerine bir araştirma. Turkish Journal of Primary Education, 6 (2), 157-179. Doi: https://doi.org/10.52797/tujped.1014824 